\title{
NOTAS FITOPATOLÓGICAS
}

\section{SELEÇÃO DE GENÓTIPOS DE SOJA RESISTENTES A DUAS ESTIRPES DE Soybean mosaic virus}

\author{
ÁlVARO M. R. ALMEIDA, LEONES A. ALMEIDA \& ROMEU A. S. KIIHL
}

Embrapa Soja, Cx. Postal 231, 80001-970, Londrina, PR, e-mail: almeida@cnpso.embrapa.br

(Aceito para publicação em 06/10/2000)

Autor para correspondência: Álvaro M.R. Almeida

\section{ABSTRACT \\ Screening of soybean genotypes for resistance to two strains of Soybean mosaic virus}

Soybean mosaic virus (SMV) is the most prevalent virus on soybeans (Glycine max) throughout the world. It causes mottling on seeds and has been associated with yield reduction. Recently, a new strain (SMV 95-1) was found infecting resistant cultivars, causing dwarfing and systemic necrosis. In a screening test carried out with the strains SMV
95-1 and SMV 95-2 on the germplasm collection, several resistant cvs. Embrapa 60, Embrapa 61, Embrapa 62, Embrapa 66 , Embrapa 133, Embrapa 134, Embrapa 135, and Embrapa 136 were identified as resistant to both strains. The resistant genotypes may serve in future soybean breeding programs in Brazil.
Soybean mosaic virus (SMV) é considerado como o mais prevalente na cultura da soja [Glycine max (L.) Merr.], em todo o mundo (Ford et al., Resumens da IV Conferencia Mundial de Investigación en Soya. V3, p. 1312, 1989). No Brasil, o SMV tem importância por contribuir para o descarte de lotes de sementes e redução de rendimento (Almeida et al., Documentos, $N^{\circ}$ 63, Embrapa Soja, 1994). A única forma de controlar essa virose é através do uso de cultivares resistentes.

Em 1995, identificou-se a presença de nova estirpe do SMV, denominada SMV 95-1, pertencente ao grupo G5 (Almeida et al., Arq. Biol. Tecnol. 38: 1095. 1995), atualmente disseminada no Brasil Central, causando nanismo e necrose sistêmica de cultivares consideradas resistentes. Genótipos de soja, foram inoculados mecânicamente com as estirpes dos grupos G1 e G5 do vírus. O grupo G1 é o mais comumente encontrado nas diferentes regiões produtoras de soja do Brasil, embora as novas cultivares liberadas aos produtores sejam resistentes a esta estirpe. As avaliações foram feitas aos 30 dias após a inoculação, contando o número de plantas infectadas, exibindo sintomas típicos da virose. As plantas assintomáticas foram indexadas, através do teste de ELISA indireto (Koenig, J. Gen. Virol. 55: 55, 1981) e não apresentaram reação positiva (Tabela 1). Os genótipos considerados resistentes às duas estirpes foram as cvs. Embrapa 60, Embrapa 61, Embrapa 62, Embrapa 66, Embrapa 133, Embrapa 134, Embrapa 135 e Embrapa 136. As cvs. Embrapa 58, Embrapa 63 e Davis apresentaram reações diferenciadas em relação às estirpes testadas.

Os genótipos resistentes podem ser utilizados como progenitores resistentes nos programas de melhoramento por possuirem características de boa adapatação às principais regiões produtoras de soja no Brasil.

TABELA 1 - Reação de genótipos de soja (Glycine max)inoculados mecânicamente com duas estirpes (G1 e G5) doSoybean mosaic virus (SMV) em condições de casa de vegetação

\begin{tabular}{lcc}
\hline \hline Genótipo & $\begin{array}{c}\text { Estirpe SMV } \\
\mathbf{9 2}-\mathbf{1}(\mathbf{G 1})\end{array}$ & $\begin{array}{c}\text { Estirpe SMV } \\
\mathbf{9 5}-\mathbf{1}(\mathbf{G 5})\end{array}$ \\
\hline Santa Rosa (controle suscetível) & $17 / 17^{*}$ & $12 / 12^{*}$ \\
Embrapa 26 & $40 / 40$ & $36 / 35$ \\
Embrapa 30 & $15 / 14$ & $16 / 16$ \\
Embrapa 58 & $18 / 00$ & $19 / 11$ \\
Embrapa 60 & $17 / 00$ & $21 / 00$ \\
Embrapa 61 & $17 / 00$ & $19 / 00$ \\
Embrapa 62 & $16 / 00$ & $17 / 00$ \\
Embrapa 63 & $16 / 07^{\mathrm{ne}}$ & $20 / 20$ \\
Embrapa 66 & $17 / 00$ & $20 / 00$ \\
Embrapa 133 & $16 / 00$ & $18 / 00$ \\
Embrapa 134 & $15 / 00$ & $17 / 00$ \\
Embrapa 135 & $17 / 00$ & $19 / 00$ \\
Embrapa 136 & $18 / 00$ & $19 / 05^{\mathrm{ne}}$ \\
Davis (controle resistente) & $19 / 00$ & $16 / 16$ \\
\hline
\end{tabular}

$* \mathrm{~N}^{\mathrm{o}}$ plantas inoculadas $/ \mathrm{n}^{\mathrm{o}}$ plantas infetadas;

${ }^{n e}$ Plantas com sintomas de necrose sistêmica.

Plantas assintomáticas foram indexadas por ELISA indireto, com resultado negativo. 